\title{
Florida Dairy Farm Situation and Outlook 20041
}

\author{
Russ Giesy, Albert De Vries, Calvin Covington, Richard Kilmer, Dave Bray, and Dan Webb ${ }^{2}$
}

Dairy farming is an important part of Florida's agricultural industry. Milk and cattle sales from dairies contributed about $\$ 390$ million to Florida's economy in 2002, about $\$ 72$ million (17\%) less than in 2001. Of that decrease, $3 \%$ was due to decreased production while $14 \%$ was due to decreased at-farm milk price.

\section{Situation}

The Florida Agricultural Statistics Service has indicated that there were about 147,000 dairy cows in Florida at the start of 2003 compared to 152,000 cows on 209 dairy farms at the start of 2002. That reflects a decline of 5,000 cows during 2003 and an 8,000-cow decrease since the start of 2001. A factor in this smaller herd size was a relatively higher cost of replacement cows. The 2002 average price per head for replacement cows was $\$ 1800$, up $23 \%$ from $\$ 1460$ in 2000 .

The Dairy Business Analysis Program (DBAP) is a cooperative effort of the Universities of Florida and Georgia, Southeast Milk Inc., and Southeast National Dairy Herd Improvement Association, Inc. (DHIA). This project annually surveys participating dairy farms about their revenues, expenses, and investments. DBAP data of 2002 showed that the average mailbox milk price received was $\$ 16.08$ per cwt milk sold, compared to $\$ 18.27$ in 2001 . The total revenues were $\$ 17.53$, total expenses were $\$ 18.34$ and net farm income was $-\$ .80$. Further, debt per cow at the end of 2002 was $\$ 812$ (59\%) higher than at the start of the year. This level of profitability was the lowest in the DBAP series since that set in 1995. The 2003 data is expected to show performance similar to or worse than 2002.

The number of US milk cows has declined. USDA estimated that the November 2003 herd was 82,000 head less than November 2002 and further culling was expected in December due to attractive cull cow prices. The decrease in cow numbers was also driven by the 32,724 cows sold as a result of the Cooperatives Working Together program. Milk production per cow in the most recent months has shown slight improvement. This will likely be an important factor to watch in 2004.

\section{Outlook}

USDA estimates that butter fat will show healthy demand growth with butter prices nearing $\$ 1.50$ by summer. Skim solids, on the other hand, will likely

1. This document is AN147, one of a series of the Department of Animal Sciences, Florida Cooperative Extension Service, UF/IFAS. Published February 2004. Please visit the web site at http://edis.ifas.ufl.edu.

2. Russ Giesy, Multi-County Dairy Agent IV, Sumter County; Albert de Vries, Assistant Professor, Department of Animal Sciences, UF/IFAS; Calvin Covington, Southeast Milk, Inc.; Richard Kilmer, Professor, Department of Food and Resource Economics, UF/IFAS; David Bray, Extension Agent IV, Department of Animal Sciences, UF/IFAS; Daniel Webb, Professor, Department of Animal Sciences, UF/IFAS; Florida Cooperative Extension Service, UF/IFAS, Gainesville, FL 32611

The Institute of Food and Agricultural Sciences (IFAS) is an Equal Employment Opportunity - Affirmative Action Employer authorized to provide research, educational information and other services only to individuals and institutions that function without regard to race, creed, color, religion, age, disability, sex, sexual orientation, marital status, national origin, political opinions or affiliations. For information on obtaining other extension publications, contact your county Cooperative Extension Service office. Florida Cooperative Extension Service / Institute of Food and Agricultural Sciences / University of Florida / Larry R. Arrington, Interim Dean 
remain at or below the $\$ .80$ support price, although lower retail prices in the winter and spring of 2004 could boost demand.

Our current projection is that 2004 milk prices will average about $\$ 0.50$ to $\$ 1.00$ per cwt. more than in 2003. Reasons for this increase include: continuing weak milk production, fewer dairy cows, milk per cow increases lower than average due to higher feed costs, past low milk prices, forage challenges, and BST rationing. Milk per cow production is still relatively low in some major dairy states, especially California, New York and Pennsylvania. The overall economy continues to improve, which should result in improved product demand. Restaurant sales are increasing and consumer confidence is improving. A small increase in demand makes a big impact.

Re-emergence of MILC payments may delay some herd liquidations, which in turn could limit milk price increases. Other factors that could hamper increases in milk prices are that California may rebound more quickly in milk production per cow or the weather could favor higher production of forages. Threats include lower demand for dairy products due to consumer concern about BSE (mad cow disease) or another terrorist attack.

The following are projected ranges of central Florida (3.5) milk prices for 2004:

$$
\begin{aligned}
& \text { January - } \$ 15.60-\$ 16.10 \\
& \text { February - } \$ 15.09-\$ 15.59 \\
& \text { March - } \$ 15.00-\$ 15.50 \\
& \text { April - } \$ 14.94-\$ 15.44 \\
& \text { May - \$14.93-\$15.43 } \\
& \text { June - \$15.44-\$15.94 } \\
& \text { July - \$16.89-\$17.39 }
\end{aligned}
$$

August - \$17.95-\$18.45

September - \$18.22-\$18.72

October - \$18.42-\$18.92

\author{
November - $\$ 17.73-\$ 18.23$ \\ December - \$16.26-\$16.76 \\ Average $\$ 16.82$
}

\section{Background Information, the Challenge of Dairying in Florida}

\section{Production Challenges}

Florida's warm and humid climate is not ideal for dairy cattle that evolved during centuries of selective breeding in the relatively moderate climates of northern Europe. Heat stress has been shown to reduce production by $25 \%$ by reducing feed intake and increasing health problems such as mastitis, lameness and reproductive delay. Mastitis has been estimated to cost producers at least $\$ 300 /$ cow/year. Udder, feet and reproductive health challenges cause the culling of nearly $30 \%$ of cows each year. Higher replacement costs prohibit some dairies from culling the less productive animals, and this lowers total herd production and profitability.

\section{Economic Challenges}

Florida's dairy producers operate under a difficult economic situation. Despite a geographic difference and a product that's difficult to transport, they increasingly compete in a national and international marketplace. Negotiating consistently profitable milk prices has become increasingly difficult for Florida's dairy cooperative because larger handlers from outside the southeast are pushing to gain market share. Ultimately they would like to control Florida's growing market with its high fluid use and resulting higher price.

Milk price volatility has made the dairy farm economic situation in the 1990s challenging. DBAP data has shown that milk prices ranged from $\$ 15.51$ in 1995 to $\$ 18.56$ in 1998 , averaging $\$ 17.41$ from 1995-2001. Price volatility continues to create difficulties for producers since costs of production are much less variable than milk prices. The same DBAP-participating dairies averaged $\$ 17.61$ total expense per cwt. from 1995-2001. This is about $25 \%$ higher than a national average. 
The size of Florida's dairies requires large investments, over $\$ 1.5$ million on average. But the return to invested capital is generally insufficient. The DBAP-participating dairies' average return on assets ranged from $0 \%$ in 1995 to $9 \%$ in 2001 . This rate of return discourages new investments. Florida lost a third of its dairy farms in the 1990s.

\section{Environmental Challenges}

Dairies face increased regulation due to social pressure. Larger herds attract the attention of neighbors and activists concerned with odors, flies, and potential losses of nutrients that influence water quality.

The greatest reason for the environmental issues facing Florida dairy producers is the high concentration of animals on farmland. High-producing cows may consume 100 pounds of feed and 50 gallons of water per day. They may excrete 195 pounds of manure and urine. Florida dairies average nearly 730 cows and about $50 \%$ of them raise young replacement cattle as well. Thus, there is an extremely high volume of nutrients flowing through the dairy system. Even minuscule percentages of these nutrients, if lost, could command attention of regulatory agencies. Further, if cow densities on land become fixed by regulatory action, new constraints on herd size will forever limit most farms' opportunity to grow, dooming them to eventual inefficiency and discontinuation.

The cost of nutrient handling systems that will meet the future requirements of environmental regulatory agencies is unknown and perceived to be a major constraint to dairies as they commit to the future. These costs have two parts; (a) the original investment costs of engineering and putting the new systems in place and (b) operating and maintaining the systems well into the future. These systems, incorporating significant levels of new technology, have been implemented to ensure that dairies efficiently handle nutrients in an environmentally friendly manner. The UF/IFAS Extension Service is helping to determine the cost of implementing and operating these new systems so as to aid management decisions for these dairies. Also, the information will be valuable to many others that have yet to develop their best responses to environmental regulation.
Size and location differences among dairies significantly affect nutrient handling system expense. Additionally, different types of systems have differing initial investment and operating expenses. Dairies that employ such new systems take on a competitive disadvantage since investing in these new systems generally does not generate a positive return.

\section{Sources}

Much of the information for this report is from the World Wide Web. To make the most up-to-date numbers available to you, the text above contains hyperlinks to the following sites:

\section{- U.S. Dairy Markets and Outlook Archive:} http://www.nmpf.org/meData/outlook.cfm

\section{- National All-Jersey Equity Newsletter:}

http://www.usjersey.com/NAJ/equitynews.pdf

\section{- USDA's National Agricultural Statistics} Service:

Milk Production:

http://usda.mannlib.cornell.edu/reports/nassr/ dairy/pmp-bb/

Dairy Product Production:

http://usda.mannlib.cornell.edu/reports/nassr/ dairy/pdp-bb/

Dairy Product Inventories:

http://usda.mannlib.cornell.edu/reports/nassr/ other/pcs-bb/

Dairy Product Prices:

http://usda.mannlib.cornell.edu/reports/nassr/ price/dairy/

\section{- USDA's AMS Dairy Programs, Federal} Order Prices:

Class I: 
http://www.ams.usda.gov/dyfmos/mib/ advanprc.pdf

Others:

http://www.ams.usda.gov/dyfmos/mib/ classprcacnmt.pdf

Federal Order Formulas:

http://www.ams.usda.gov/dyfmos/mib/ price_form_2003.htm

- AMS Dairy Market News:

Fluid Sales, Coop. Class I Prices:

http://www.ams.usda.gov/dairy/mncs/ weekly.htm

- USDA's Economic Research Service:

Commercial Disappearance, Price

Projections, Etc.:

http://usda.mannlib.cornell.edu/reports/erssor/ livestock/ldp-mbb/

- USDA's Farm Service Agency:

Information on the MILC Program:

http://www.fsa.usda.gov/dafp/psd/MILC.htm

Information on the Price Support Program:

- Notices to the industry:

http://www.fsa.usda.gov/daco/notices.htm

Announcements, Invitations, Etc.:

http://www.fsa.usda.gov/daco/dairy.htm\#Inv

Inventory Reports and Statistics:

http://www.fsa.usda.gov/daco/reports.htm

\section{- Bureau of Labor Statistics:}

Retail Prices:

http://www.bls.gov
- Federal Register:

Formal Notice of Regulatory Actions:

http://www.gpoaccess.gov/fr/index.html

- Chicago Mercantile Exchange Daily Prices:

Cash Cheese and Butter Prices; Milk and

Butter Futures:

http://www.cme.com/dta/hist/

daily_settlement_prices.html?type=com

Daily Dairy Report:

http://www.dailydairyreport.com/

- Florida Dairy Business Analysis Program:

Florida's Cost of Production:

http://dairy.ifas.ufl.edu/fldbc.html

http://edis.ifas.ufl.edu/DS174 